\author{
A. Kostyshin, Cand. Sc. (Econ.), Assoc. Prof., \\ orcid.org/0000-0003-0067-6935, \\ L. Tibilova, Cand. Sc. (Econ.), Assoc. Prof., \\ orcid.org/0000-0002-5204-9602
}

Lviv National Agrarian University, Lviv, Ukraine, e-mail: kostushn@ukr.net; Mila-27@ukr.net

\title{
INDICATORS OF ENVIRONMENTAL SUSTAINABILITY OF AN AREA IN MANAGERIAL DECISIONS
}

Purpose. To develop methods for the introduction of the correction coefficients of relief to clarify the environmental sustainability of a farmland area and differentiation of the coefficients for steepness of slopes and truncation of soil.

Methodology. The method for calculation and introduction of the coefficient of morphological stability of relief $K_{c}$ to the formula of the environmental sustainability of a territory with medium and strongly truncated lands, as well as with weakly or not truncated ones was developed. For this purpose the calculative and constructive, comparative method and the method of analogy are used. The method has been tested on the territory of Chernivtsi region.

Findings. The rates of environmental sustainability $K_{\text {e.s. }}$ of an agricultural area with corresponding characteristics of relief have been adjusted. Furthermore, $K_{\text {e.s. }}$ coefficients in the context of different degrees of land truncation and in the context of different intervals of steepness of slopes have been calculated. Calculation of ecological sustainability in Chernivtsi region and its characteristic structure of agricultural land and erosion performance have been also adjusted.

Originality. The definition "erosion making factors" has been argued for integrating the indicators of the slope steepness and the degree of truncation. It is proposed to use ratios of environmental sustainability, adjusted for relief, which, unlike the traditional methods, takes into consideration the specific integrated indicators.

Practical value. Application of the proposed methodology of coefficient correction for relief and erodibility of lands distributed in the range of 0.7 to 1.0 is able to present a more realistic picture of environmental sustainability of an area in terms of various organizational and territorial units (village, town and city councils, administrative areas, including newly formed administrative-territorial division) and use them when making a design and management solutions.

Keywords: erosion making factors, the coefficient of environmental sustainability, slope steepness, the degree of truncation, land

Introducrion. One of important factors of evaluation of the existing land use is the indicator of environmental sustainability of the territory. The level of environmental sustainability of a specific area of land of economic structures conditions managerial and design decisions on rational land use and its protection, affects the strategy for rural development. Therefore, the problem of obtaining its accurate assessment at all levels (from a separate land, a land plot to the territory of local councils, districts, regions and land fund of the country as a whole) is relevant and requires its solution.

Unsolved problems. In order to assess the ecological stability of the territory, various methods based on the consideration of anthropogenic loading on it, on the indices of the ratio of areas of conditionally stable lands to arable land, and also on the determination of the ecological stability factor are developed and applied. Each of these techniques takes into account and depicts the specific aspects of environmental safety assessment of the territory. But, in general, there are no synergistic approaches to the problem.

Analysis of the recent research and publications. In the late 1980's to early 1990's, Slovak scientists (I. Ryborski, E. Hojke, V. Heiniger, E. Klementova) proposed and formulated the methodology of the influence of land compound assessment on the environmental sustain-

(C) Kostyshin A., Tibilova L., 2018 ability of an area, which allowed to a certain extent comparing, evaluating and optimizing the structure of land use. In further studies, P.P. Borshchevsky developed and applied this technique for Volyn region.

Kanash O. P. proposes ecological preconditions for optimization of land use by means of the index of ecological mismatch of the existing use of land and the excess of their permitted cultivation [1].

The authors of this article have tested the methodology for environmental sustainability assessment in Chernivtsi region [2] in terms of district areas and developed by the materials a cartogram of environmental sustainability of the region. As a result of this approach, it became possible not only to detect stable or unstable territories, but also to make a comparative analysis of the existing land use patterns with the maximum allowable environmental dimensions of human activity and establish a correlation of the development of land degradation processes. Later on, it is proposed to introduce a correction factor for relief on agricultural land and perennial plantings [3].

Unsolved aspects of the problem. The method for determining the coefficient of environmental sustainability of the territory provides for only two positions for the relief factor ( 0.7 for eroded lands and 1.0 - for not eroded ones).

In cases, where some parts of the territory vary greatly in terms of topography, differentiation of the correc- 
tion factor becomes important. Thus, the magnitude of the coefficient is affected not only by natural and geographical area allocation of land, but the terrain characteristics such as the slope steepness and extent of truncation.

Objectives of the article. The purposes of the article are as follows:

1. To expand the concept of "erosion making factors", their dual nature: the steepness of slopes and truncation of lands.

2. To clarify the factor of environmental sustainability of areas for different types of agricultural land with regard on erosion making factors.

Presentation of the main research. Vast expanses of lands of our country in the past have caused extensive system of land use, farming and even extensive type of thinking and living. The expansion of arable land has always been unique, though disastrous for the future means of production increase in plant growing. Sustainable land use and protection of land resources cover three groups of issues: protection of ground from exhaustion and improvement of its fertility - economic group; protection against pollution and its prevention environmental group; maintaining the minimum living standards, especially in rural areas - socially oriented group [4].

In Ukraine, in accordance with the Law of Ukraine "On the main principles (strategy) of the state environmental policy of Ukraine for the period until 2020", the first of the main principles of National Ecological Policy proclaims the strengthening of the role of environmental management in order to achieve the equality of the three scenarios: ecological, economic and social. In the basis of this law, it is envisaged to achieve a deceleration of the pace of deterioration of the ecological situation by reforming the system of state ecological management, which will include separation of the functions of protection of the natural environment and economic activity on the use of natural resources, the implementation of European environmental norms and standards, improvement of environmental accounting systems and control, introduction of financial and economic mechanisms of stimulation of ecologically oriented structural transformations in economics, widespread environmental awareness.

Due to the inability to increase the area of landscapes because of social, economic and organizational obstacles, for which there is no anthropogenic load, the problem of harmoniousness of society with nature is extremely complicated.

Degradation of land resources requires carrying out science-based public policy as for the use and protection of land, establishing a mechanism for preservation and improvement of national wealth - productive land.

Besides the destructive processes on farmlands on the slopes of the Carpathian Mountains, there occur large floods, mudslides, landslides and avalanches that cause significant damage to soil and natural ecosystems in general. As a result of these natural disasters, the slopes become exposed, the forest plantation becomes impossible and decreases the reproductive capacity of the biosphere. In such circumstances, we need to regulate and reproduce natural-territorial complexes as complex ecosystems $[5,6]$.

In modern terms, the environmental situation of land is estimated by anthropogenic loading, for ecological and economic balance of an area, the index of environmental discrepancy of the real land use and excess of the permissible plow [1] and the factor environmental sustainability [7]. The anthropogenic burden make estimates and classifies its loads by nine positions from the highest to the lowest parts. The ratio of absolute intensity of ecological and economic state of land characterizes propensity property of a territory development towards the use of technogenic systems with very strong anthropogenic influence. The ratio of the area of a group of lands with a higher anthropogenic load to the area of a group of lands with lower anthropogenic disturbance is the ratio of the relative tensions of the ecological and economic status of the territory of $K_{v}$. It characterizes the degree of ecological and dangerous development of the territory and indicates the displacement of its state as a natural and anthropogenic system either in the direction of intensification of anthropogenic influence, or in the direction of building capacity for the restoration of natural properties. Decrease in $K_{v}$ means the tendency of reduction of environmental tension, restoration of natural equilibrium, maintenance of the necessary level of recreational and nature protection territories.

The ability of the territory or natural-technological system to withstand anthropogenic influences and maintain an ecological balance determines its natural security. It is known that the greater the stability of the ecosystem is, the higher the biological diversity of the ecosystem gets. Similarly, the greater the stability or security of the territory is, the greater its landscape diversity is. The presence of various environmental protection zones and the uniform distribution of areas with natural biogeocoenoses within the territory increase its natural security.

A higher degree of ecological and economic balancing of the territory can be achieved through conscious formation of new socio-economic systems, shared with the bodies of self-government, business, science and population [8].

The index of environmental discrepancy of the real land use and excess of the permissible plow [1] evaluates environmental condition on the natural geographic areas and provinces.

The coefficient of environmental sustainability of the territory is based on ecological stability of individual lands and allows assessing the stability of various political subdivisions through their area and structures both qualitatively (unstable, relatively stable, medium stable and sustainable) and quantitatively (through the value of the coefficient).

Index of environmental sustainability of a territory is used for monitoring of land, which includes a set of observations of the state of land fund for timely detection of changes taking place under the influence of human activities when developing land management projects that provide environmental and economic justification 
for crop rotation and land management, and for forecasting land use, prevention and elimination of the consequences of negative processes, control over land and land protection, and others.

The integrity of the environmental potential, the mutual transformation of economic and environmental effects over an indefinite period of time result in the expansion of the spectrum of measurements and estimates. Rationality of nature management is characterized by indicators of the structure of the use of the territory, the quality of the ecological potential of land. To assess the impact of qualitative composition of lands on the ecological stability of the territory, we propose to calculate the coefficients of ecological stability of the territory.

The composition of land in any natural-territorial complex or administrative-territorial formation largely determines their ecological stability. It has been proved that with the growth of agricultural development and land plots due to the effect of objective agroecological laws there is an unbalanced load on them and the ecological stability of landscapes decreases significantly, which leads to degradation of the soil, the development of erosion processes and, conversely, with an increase in the proportion of environmentally sustainable land more stable landscapes are formed in the structure of land (forests, wetlands).

Assessment of the stability of the territorial structures remains popular in modern environmental and economic conditions. However, at this stage of scientific knowledge, the need for integrated use of various methods and approaches to solving the problem of the formation of stable systems of agricultural land becomes apparent.

The algorithm for the introduction of the correction coefficient was tested on agricultural land in the Chernivtsi region. This area is small compared to other regions of Ukraine (the smallest areally), but it is marked by great diversity of natural conditions. Placing of certain soil types and subtypes is caused by natural landscapes of the region, which forms three well defined provinces: Carpathian mountain forest, Precarpathian highland meadow forest and Prut-Dniester highland steppe, each of which is characterized by its peculiar soil surface.

Natural-agricultural zoning allows taking into account the diversity of natural and economic indicators, territorial and economic features of the structure of the land fund and the state of soil cover, geomorphological, natural-climatic, erosion and other differences of territories. Detailed zoning of the territory allows fully taking into account the territorial differences of natural and economic conditions, which will provide more accurate knowledge of regional features of the area, data on the qualitative state of soils, water mode, emissions of enterprises, the nature and directions of geochemical migration, etc. [9].

The overall coefficient of environmental sustainability of a territory $\left(K_{\text {e.s. }}\right)$ is usually calculated using the formula

$$
K_{\text {e.s. }}=\frac{\sum K_{1 i} \times P_{i}}{\sum P_{i}} \times K_{p},
$$

where $K_{l i}$ is the factor of environmental sustainability of the $i^{\text {th }}$ sort land; $P_{i}$ is the area of land of the $i^{\text {th }}$ sort; $K_{p}$ is the coefficient of morphological stability of a relief ( $K_{p}=1$ for stable areas and $K_{p}=7$ for unstable ones) [7].

Under this formula, it is traditionally to introduce the rate 0.7 - in condition of difficult terrain in all areas, which in this case are in the foothills and mountainous area of Chernivtsi region; in the forest-steppe zone it is not tabled. In our research we attempted to differentiate this correction coefficient for relief in the range of 0.7 to 1.0 taking into account the fact that in Chernivtsi region there are $50.7 \%$ of non-truncated lands, $31.7 \%$ of slightly truncated, $13.8 \%$ of medium truncated and $3.8 \%$ of severely truncated lands.

Moreover, in the foothills and mountainous area there are some non-truncated lands with slopes of 0 to $3^{\circ}$. Since the area is mountainous, according to traditional methods, $K_{p}$ should be introduced. However, in case of non-truncated land, in our opinion, it is not advisable to introduce $K_{p}$. In the land of forest-steppe there are slopes with steepness of 3 to $5^{\circ}$, of 5 to 70 or more. In these conditions $K_{p}$ should be introduced, despite the natural geographical area. With increasing degree of truncation in most soils, the resistance to flushing decreases. Turf-podzolic soils are an exception: here, with an increase in the size of the truncation, closer to the surface, an iluvial horizon is more resistant to erosion (due to the clay fraction and the ferrous and iron oxides of iron and aluminum).

In the natural conditions of the Carpathian Mountains it is impermissible to delay the protection of soil from erosion. In this case, not only the soil and its fertility are lost, the crops are damaged and the yield of crops falls, but also the environment is dangerously polluted.

Under one and the same rainfall, erosive processes increase over considerable length and slope steepness, especially if they have a longitudinally convex and transverse concave shape, a large drainage area, and the intersection of slopes with hollows. The depth of the dismemberment (local bases of erosion) of the PrutDniester interflux of Chernivtsi region (forest-steppe zone) reaches $75-175 \mathrm{~m}$, the foothills of the Carpathians are $50-150 \mathrm{~m}$, and the density is $1.2-1.8$ and $0.6-1.6 \mathrm{~km} / \mathrm{km}^{2}$, respectively.

In some places, for example, in the Transnistrian part of the forest-steppe zone, these indicators reach $150-220 \mathrm{~m}$ and $2 \mathrm{~km} / \mathrm{km}^{2}$, respectively. Slopes with steepness of more than 1 degree, on which the formation of surface runoff is already taking place, occupy about $90 \%$ of the territory in Chernivtsi region. That is, in Chernivtsi region, as well as in many other regions, the area is not uniform on the relief [10], and rates of relief such as the degree of truncation and slope steepness are generally characterized by different correlation.

This draws the logical conclusion that it is appropriate to differentiate the correction for relief in the range of 0.7 to 1.0 (Table 1 ).

With this differentiation the extreme values of the range are assigned as follows: for severely truncated land with slopes of more than $7^{\circ} K_{p}=0.7$, for non-truncated land with slopes steepness $0-3^{\circ} K_{p}=1.0$; the intermedi- 
Table 1

Distribution of the correction coefficient

\begin{tabular}{|l|c|c|c|c|}
\hline $\begin{array}{l}\text { Steepness } \\
\text { of slope }\end{array}$ & $0-3^{\circ}$ & $3-5^{\circ}$ & $5-7^{\circ}$ & $\begin{array}{c}\text { More } \\
\text { than } 7^{\circ}\end{array}$ \\
\hline Non-truncated & 1.00 & 0.98 & 0.96 & 0.94 \\
\hline Slightly truncated & 0.92 & 0.90 & 0.88 & 0.86 \\
\hline Medium truncated & 0.84 & 0.82 & 0.80 & 0.78 \\
\hline Severely truncated & 0.76 & 0.74 & 0.72 & 0.70 \\
\hline
\end{tabular}

ate values are distributed proportionally the erosion making factors, with preference given to indicators of slopes steepness.

Both figures (degree of truncation and slope steepness) are produced by the notion of "erosion making factors" and to some extent they limit the mode their further economic use and dictate the development of appropriate erosion and other environmental measures.

In addition to natural factors, the organizationalterritorial and technological factors, such as the placement of fields and their work areas, field roads, the structure of crops and crop rotation, the technology of growing crops, and others, are strongly influenced by the development of erosion processes.

Erosion processes have a significant diversified effect on the soil cover. Losses of $10 \mathrm{~cm}$ of a humus layer of 1 hectare transfer more than 1000 tons of soil, and from the middle and strongly-crushed - to 5 thousand tons.

Agricultural lands of Chernivtsi region have the following structure of erosion making factors.

Arable:

- the steepness of the slope: those with $0-3^{\circ}$ make $61.0 \% ; 3-50-23.1 \% ; 5-70-12.2 \%$; more than $70-$ $3.7 \%$;

- the degree of truncation: non-truncated lands make $50.7 \%$ and $31.7 \%$ are slightly truncated; medium truncated lands make $13.8 \%$ and there are $3.8 \%$ of severely truncated lands.

Perennial planting:

- the steepness of the slope: those with $0-30$ make $49.4 \% ; 3-50-26.4 \% ; 5-70-15.3 \%$; more than $70-$ $8.9 \%$;

- the degree of truncation: non-truncated - $42.5 \%$ and slightly truncated $-32.9 \%$; medium truncated $16.5 \%$ and severely truncated lands $-8.1 \%$.

Hay harvesting:

- the steepness of the slope: those with $0-30-23.1 \%$; $3-50-10.1 \%$; 5-70-38.1\%; more than $70-28.7 \%$;

- the degree of truncation: non-truncated $55.4 \%$ and slightly truncated $-8.0 \%$; medium truncated $-12.8 \%$ and severely truncated lands $-23.8 \%$.

Pastures:

- the steepness of the slope: those with $0-30-$ $23.5 \% ; 3-50-10.6 \% ; 5-70-27.7 \%$; more than $70-$ $38.2 \%$

- the degree of truncation: non-truncated - $40.0 \%$ and slightly truncated $-8.2 \%$; medium truncated $17.2 \%$ and severely truncated lands $-34.6 \%$.
On non-truncated and slightly truncated lands of the region there are, predominantly, arable lands with slope steepness $0-30$ (50.7\% on non-truncated lands and $31.7 \%$ on slightly truncated ones). Typically, for non-truncated and slightly truncated lands it is considered to be inappropriate to introduce $K_{p}$ ratio into the formula (1). But on the non-truncated lands there are about 7 thousand ha, and on the slightly truncated about 55 thousand hectares of arable land with slopes of 3 to $7^{\circ}$ or more. This arable land area is approximately equal to the entire administrative area of a district. This is another strong argument for the need to introduce $K_{p}$.

Distribution of agricultural land of the region by the degree of truncation and by the slope steepness (Table 2) suggests a considerable heterogeneity of erosion making factors influence on the environmental safety.

The structure of agricultural land by the degree of truncation and the steepness of the slope shows that non-truncated and slightly truncated lands cover more than three-quarters of all agricultural land area. More than a half of the land area has slope steepness of 0 to $3^{\circ}$, lands with slope steepness of 3 to 50 with the same degree of truncation make $16.3 \%$. In the medium and se-

Table 2

Characterization of farmland by erosion making factors

\begin{tabular}{|c|c|c|c|c|}
\hline \multirow{2}{*}{\multicolumn{2}{|c|}{$\begin{array}{l}\text { The degree of truncation } \\
\text { and the slope steepness }\end{array}$}} & \multicolumn{3}{|c|}{ Area } \\
\hline & & $\mathrm{h}$ & & $\%$ \\
\hline \multicolumn{2}{|l|}{ Non-truncated } & 1946 & & 49.3 \\
\hline \multicolumn{2}{|l|}{$0-3^{\circ}$} & 1645 & & 41.6 \\
\hline \multicolumn{2}{|l|}{$3-5^{\circ}$} & 735 & & 1.9 \\
\hline \multicolumn{2}{|l|}{$5-7^{\circ}$} & 153 & & 3.9 \\
\hline \multicolumn{2}{|l|}{ More than $7^{\circ}$} & 74 & & 1.9 \\
\hline \multicolumn{2}{|l|}{ Slightly truncated } & 1031 & & 26.1 \\
\hline \multicolumn{2}{|l|}{$0-3^{\circ}$} & 3910 & & 9.9 \\
\hline \multicolumn{2}{|l|}{$3-5^{\circ}$} & 5693 & & 14.4 \\
\hline \multicolumn{2}{|l|}{$5-7^{\circ}$} & 687 & & 1.7 \\
\hline \multicolumn{2}{|l|}{ More than $7^{\circ}$} & 222 & & 0.1 \\
\hline \multicolumn{2}{|c|}{ Medium truncated } & 565 & & 14.3 \\
\hline \multicolumn{2}{|l|}{$0-3^{\circ}$} & 445 & & 0.1 \\
\hline \multicolumn{2}{|l|}{$3-5^{\circ}$} & 1322 & & 3.3 \\
\hline \multicolumn{2}{|l|}{$5-7^{\circ}$} & 3487 & & 8.8 \\
\hline \multicolumn{2}{|l|}{ More than $7^{\circ}$} & 798 & & 2.0 \\
\hline \multicolumn{2}{|c|}{ Severely truncated } & 406 & & 10.3 \\
\hline \multicolumn{2}{|l|}{$0-3^{\circ}$} & 23 & & 0.1 \\
\hline \multicolumn{2}{|l|}{$3-5^{\circ}$} & 242 & & 0.6 \\
\hline \multicolumn{2}{|l|}{$5-7^{\circ}$} & 959 & & 2.4 \\
\hline \multicolumn{2}{|l|}{ More than $7^{\circ}$} & 283 & & 7.2 \\
\hline \multicolumn{2}{|c|}{ Overall in the region } & 3949 & & 100.0 \\
\hline Slope steepness & $0-3^{\circ}$ & $3-5^{\circ}$ & $5-7^{\circ}$ & $>7^{\circ}$ \\
\hline$\%$ & 51.7 & 20.2 & 16.9 & 11.2 \\
\hline
\end{tabular}


verely truncated lands dominate slopes of 5 to $70(11.2 \%)$ and 70 and more $(9.2 \%)$.

Taking into consideration the composition of erosion making factors of the region and differentiated correction for relief, we can adjust the ratios of environmental sustainability for all types of agricultural land in terms of spacing of the degree of slope steepness and truncation of land (Table 3). For an example, the $K_{\text {e.s. }}$ oscillations are depicted in the Figure.

In Table $3 \Pi \times K_{1} \times K_{p}^{\prime}$, where $K_{1 i}$ is the factor environmental sustainability of the ith sort land; $P_{i}$ is the area of land of the ith sort; $K_{p}$ is the coefficient of morphological stability of a relief $\left(K_{p}=1\right.$ for stable and $K_{p}=7$ for unstable areas Table 1).
The last column of the table gives the corrected coefficient of environmental sustainability $K_{\text {e.s. }}$ of the territory (in bold) in the context of the relevant land characteristics of the relief. Furthermore, it gives the coefficients of environmental sustainability in the context of land varying degrees of truncation (bold italics), and in the context of different intervals of steepness of slopes (last line).

These factors are rightly to be used when working out the projects and land management schemes, including schemes of land management and feasibility studies of land use and protection of administrative units; land management projects that provide environmental and economic assessment of crop rotation and streamline of land; land consolidation and the preparation of techni-

Table 3

Determination of the coefficients of the environmental sustainability of agricultural lands in Chernivtsi region

\begin{tabular}{|c|c|c|c|c|c|c|c|}
\hline \multirow{3}{*}{ Agricultural lands } & \multirow{3}{*}{$\mathrm{K}_{1}$} & \multirow{3}{*}{ Area, ha } & \multicolumn{4}{|c|}{ Slope steepness } & \multirow{3}{*}{$\begin{array}{l}K_{\text {e.s. }} \text { in terms } \\
\text { of lands }\end{array}$} \\
\hline & & & $0-3^{\circ}$ & $3-5^{\circ}$ & $5-7^{\circ}$ & $>7^{\circ}$ & \\
\hline & & & $\Pi \times K_{1} \times K_{p}^{\prime}$ & $\Pi \times K_{1} \times K_{p}^{\prime}$ & $\Pi \times K_{1} \times K_{p}^{\prime}$ & $\Pi \times K_{1} \times K_{p}^{\prime}$ & \\
\hline \multicolumn{8}{|c|}{ Non-truncated } \\
\hline Arable & 0.14 & 146401 & 139407.2 & 5357.1 & 1407.4 & 229.3 & 0.14 \\
\hline Perennial planting & 0.43 & 5216.4 & 4872.0 & 188.2 & 125.3 & 30.9 & 0.43 \\
\hline Hay harvesting & 0.62 & 19630.3 & 7622.5 & 805.8 & 7726.0 & 3476.0 & 0.51 \\
\hline Pastures & 0.68 & 23432.7 & 12602.1 & 1006.4 & 6087.4 & 3736.8 & 0.67 \\
\hline Overall & & 194680.4 & 164503.8 & 7357.5 & 15346.1 & 7473 & \\
\hline$K_{\text {e.s. }}$ of non-truncated lands & \multicolumn{7}{|c|}{0.25} \\
\hline \multicolumn{8}{|c|}{ Slightly truncated } \\
\hline Arable & 0.14 & 91501.9 & 36347.7 & 50075.6 & 4962.8 & 115.8 & 0.13 \\
\hline Perennial planting & 0.43 & 4034.2 & 1176.2 & 2683.7 & 173.9 & 0.4 & 0.39 \\
\hline Hay harvesting & 0.62 & 2818.9 & 538.6 & 1425.2 & 803.6 & 51.5 & 0.56 \\
\hline Pastures & 0.68 & 4777.9 & 1041 & 2746.5 & 935.8 & 54.6 & 0.61 \\
\hline Overall & & 103132.6 & 39103.5 & 56931.0 & 6876.1 & 222.3 & \\
\hline$K_{e . s .}$ of slightly truncated lands & \multicolumn{7}{|c|}{0.17} \\
\hline \multicolumn{8}{|c|}{ Medium truncated } \\
\hline Arable & 0.14 & 39897.9 & 397.7 & 10522.8 & 25580.9 & 3396.5 & 0.11 \\
\hline Perennial planting & 0.43 & 2024.1 & 15.6 & 314.4 & 1440.2 & 253.9 & 0.34 \\
\hline Hay harvesting & 0.62 & 4532 & 5 & 823.3 & 2354.8 & 1339.0 & 0.49 \\
\hline Pastures & 0.68 & 10079.9 & 31 & 1556.1 & 5494.9 & 2997.3 & 0.54 \\
\hline Overall & & 56533.6 & 449.3 & 13225.6 & 34870.8 & 7987.6 & \\
\hline$K_{\text {e.s. }}$ of medium truncated lands & \multicolumn{7}{|c|}{0.23} \\
\hline \multicolumn{8}{|c|}{ Severely truncated } \\
\hline Arable & 0.14 & 10976.4 & 101.6 & 1013.4 & 3134.3 & 6727.1 & 0.10 \\
\hline Perennial planting & 0.43 & 993.4 & 7.8 & 43.1 & 145 & 797.5 & 0.30 \\
\hline Hay harvesting & 0.62 & 8432.8 & 34.9 & 474.8 & 2621.4 & 5301.7 & 0.44 \\
\hline Pastures & 0.68 & 20248.6 & 89.7 & 889.6 & 3698.6 & 15570.7 & 0.48 \\
\hline Overall & & 40651.2 & 234.0 & 2420.9 & 9599.3 & 28397.0 & \\
\hline$K_{\text {e.s. }}$ of severely truncated lands & \multicolumn{7}{|c|}{0.30} \\
\hline Overall & & & 204290.6 & 79935 & 66692.3 & 44079.9 & \\
\hline$K_{\text {e.s. }}$ in terms of slope steepness & & & 0.20 & 0.19 & 0.32 & 0.35 & \\
\hline
\end{tabular}




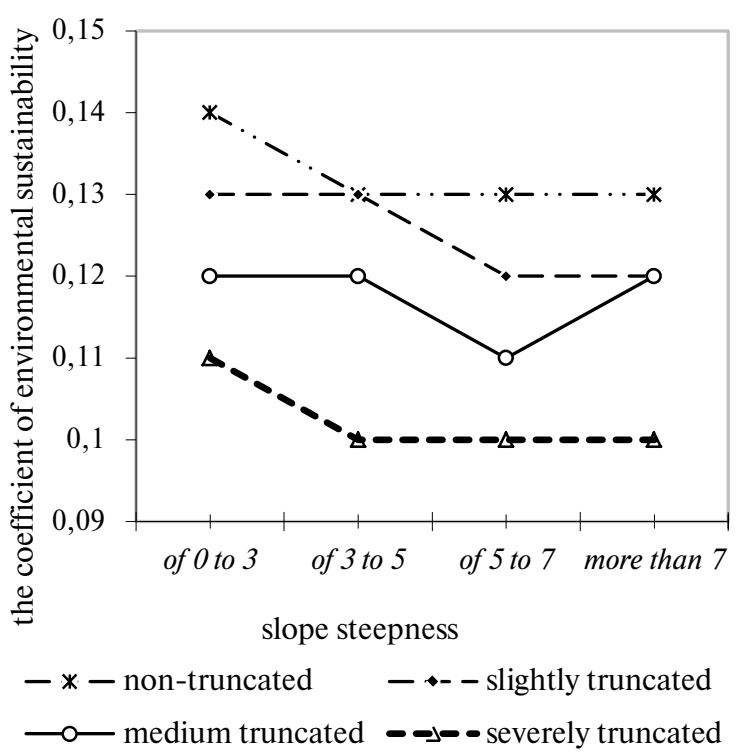

Fig. $K_{\text {es. }}$ fluctuation (with differentiated correction for erosion-forming factors) [2]

cal documentation on land management division and unification of land.

The adjusted coefficients can be used in decisionmaking and execution of special functions in the field of land use and protection, such as granting and withdrawal of land; forecasting and land use planning; monitoring of land resources and dynamics of its changes; cadastre; state control over rational use and protection of land.

The use of differentiated coefficients makes it possible to assess the level of ecological stability of different territories and compare them.

Conclusions and recommendations for further research. $K_{p}$ ratio should be introduced, despite the natural geographical area. Differentiation correction is appropriate for relief in the range of 0.7 to 1.0 .

The coefficients of ecological stability with the correction for the relief should be used when making managerial and design decisions.

Further investigation should be advisable to focus on:

- determining the impact of aggregate-size distribution index of the composition of the soil on environmental sustainability (in quantitative form) and clarification of the coefficient of environmental sustainability on this basis;

- expansion and greater use of specified factors of environmental sustainability with regard to other structures of erosion making factors (other than in conditions of Chernivtsi region);

- taking into account the type of soil and its agroindustrial groups with their characteristic soil profile, composition and height of individual profile horizons, which influence the resistance to erosion processes, soil contamination and the level of anthropogenic loading.

\section{References.}

1. Kanash, O.P., 2013. Attention to the ground - our honorable duty. Land Management Journal, 2, pp. 9-13.
2. Tibilova, L. M. and Kostyshyn, O. O., 2013. Approaches to assessing the environmental sustainability of areas. Bulletin of Lviv National Agricultural University, Economics $A P K, 20(2)$, pp.14-19.

3. Tibilova, L. M. and Kostyshyn, O. O., 2015. Ecological stability of the territory of perennial plantations. Agrarian Science Stiinta Agricola / Universitatea agrara de statdin Moldova, 2, pp. 76-81.

4. Atamanyuk, O.P., 2013. Analysis of village council land managementduring the completion of the land reform. Agrosvit, 1, pp. 18-22.

5. Dobriak, D. S. and Kuzin, N. V., 2016. Ecological and economic evaluation processes that cause degradation of land resources. Sustainable Nature, 2, pp. 105-113.

6. Kalenska, O.V. and Sakal, O. V., 2015. Agricultural landscapes: concepts, subjects and factors of transformation. Economist, 3, pp. 26-29.

7. Stepenko, O. V., 2013. Ecological bases of rational use of agricultural land. In: Environmental Economics and Environment. Zb.nauk.pr. Kyiv, pp. 146-153.

8. Shevchuk, V.Y. Environmental management [online]. Available at: <https://www.google.com.ua/knigi/ 80-ekologchne-upravlnnya-shevchuk-vya.html> [Accessed 3 April 2017].

9. Natural districts of Chernivtsi region [online]. Available at: <http://collectedpapers.com.ua/nature_of_ chernivtsi_region/prirodni-rajoni-cherniveckoyioblasti> [Accessed 22 March 2017].

10. Statistical Yearbook of Chernivtsi region 2014 [online]. Available at: <www.cv.ukrstat.gov-.ua/publiy/ kompl/zb/shor2014.pdfhttp://collectedpapers.com.ua/ nature_of_chernivtsi_region/prirodni-rajoni-cherniveckoyi-oblasti> [Accessed 2 February 2017].

\section{Показники екологічної стабільності території при прийнятті управлінських рішень}

\section{О. О. Костишин, Л. М. Тібілова}

Львівський національний аграрний університет, м. Львів, Україна, e-mail: kostushn@ukr.net; Mila-27@ukr.net

Мета. Розробка методики введення поправочних коефіцієнтів на рельєф для уточнення екологічної стабільності території й диференціація цих коефіцієнтів за крутістю схилів і ступенем змитості земель.

Методика. Розроблена методика розрахунку та уведення коефіцієнта морфологічної стабільності рельєфу $\left(K_{p}\right)$ до формули екологічної стабільності території як на сильно- й середньозмитих землях, так і на незмитих і слабозмитих землях. При цьому застосовані розрахунково-конструктивний, порівняльний методи й метод аналогії. Методика апробована на території Чернівецької області.

Результати. Відкоректовані коефіцієнти еколо-

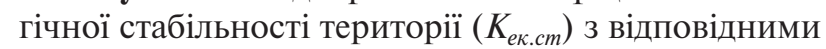
характеристиками рельєфу. Крім того, обчислені коефіцієнти екологічної стабільності в розрізі земель різного ступеню змитості та у розрізі різних 
інтервалів крутості схилів. Уточнений розрахунок $K_{\text {ек.сm }}$ на території Чернівецької області з характерною для неї структурою сільськогосподарських земель і показників еродованості.

Наукова новизна. Аргументується використання дефініції „ерозійноформуючі фактори“ для інтеграції показників крутості схилу й ступеню змитості. Пропонується використовувати коефіцієнти екологічної стабільності, уточнені поправкою на рельєф, що, на відміну від традиційної методики, передбачають урахування конкретних інтегрованих показників.

Практична значимість. Застосування запропонованої методики поправки до коефіцієнта на рельєф і еродованість земель, розподілену в інтервалі від 0,7 до 1,0 , дає можливість отримати реальну картину екологічної стабільності території в розрізі різних організаційно-територіальних утворень (сільської, селищної, міської рад, адміністративних районів, у тому числі й сформованих за новим адміністративно-територіальним поділом) і застосовувати їх при прийнятті проектних і управлінських рішень.

Ключові слова: ерозійноформуючі фактори, коефіцієнт екологічної стабільності, крутість схилу, ступінь змитості, землі

\section{Показатели экологической стабильности территории при принятии управленческих решений}

\section{А. А. Костышин, Л. М. Тибилова}

Львовский национальный агарный университет, г. Львов, Украина, e-mail: kostushn@ukr.net; Mila-27@ukr.net

Цель. Разработка методики введения поправочных коэффициентов на рельеф для уточнения экологической стабильности территории и дифференциация этих коэффициентов, учитывая крутизну склонов и степень смытости земель.

Методика. Разработана методика расчета и введения коэффициента морфологической стабильности рельефа $\left(K_{p}\right)$ в формулу экологической ста- бильности территории как на сильно и среднесмытых землях, так и на несмытых и слабосмытых землях. При этом применены расчетно-конструктивный, сравнительный методы и метод аналогии. Методика апробирована на территории Черновицкой области.

Результаты. Откорректированы коэффициенты экологической стабильности территории $\left(K_{\text {ек.сm }}\right)$ с соответствующими характеристиками рельефа. Кроме того, рассчитаны $K_{\text {ек.ст }}$ в разрезе земель разной степени смытости и в разрезе различных интервалов крутизны. Уточненный расчет коэффициента экологической стабильности на территории Черновицкой области с характерной для нее структурой сельскохозяйственных земель и показателей эродированности.

Научная новизна. Аргументируется использование дефиниции ,эрозионноформирующие факторы“ для интеграции показателей крутизны склона и степени смыва. Предлагается использовать коэффициенты экологической стабильности, уточненные поправкой на рельеф, которые, в отличие от традиционной методики, предусматривают учет конкретных интегрированных показателей.

Практическая значимость. Применение предложенной методики поправки к коэффициенту на рельеф и эродированность земель, распределенную в интервале от 0,7 до 1,0, дает возможность получить реальную картину экологической стабильности территории в разрезе различных организационнотерриториальных образований (сельского, поселкового, городского советов, административных районов, в том числе и сформированных по новому административно-территориальному делению) и применять их при принятии проектных и управленческих решений.

Ключевые слова: эрозионноформирующие фактоpы, коэффициент экологической стабильности, крутизна склона, степень смытости, земли

Рекомендовано до публікації докт. екон. наук П.П.Зарембою. Дата надходження рукопису 12.04.17. 